\title{
Influence of Norepinephrine, Growth Hormone and Fasting on FFA Mobilization and Glucose Metabolism in Lean and Obese Subjects
}

\author{
E. BALASSE \\ Clinique Médicale et Laboratoire de Médecine Expérimentale, Université Libre de Bruxelles, \\ Bruxelles, Belgium
}

Received March 28, 1967

\begin{abstract}
Summary. The influence of norepinephrine (NE), human growth hormone ( $\mathrm{HGH}$ ) and fasting on $\mathrm{FFA}$ mobilization and carbohydrate metabolism has been studied in 47 obese females and 72 nonobese control subjects ( 35 females and 37 males). - Weight-related doses of NE infused for $2 \mathrm{~h}(0.1 \gamma / \mathrm{kg} / \mathrm{min})$ induced a much greater rise in plasma FFA and blood glucose concentrations in obese than in normal subjects. With a fixed dose $(10 \gamma / \mathrm{min}$ for $2 \mathrm{~h})$, FFA response was still significantly higher in the overweight than in the lean subjects, while glucose reponses were similar in both groups. Among the control subjects, males and females behaved similarily. - The plasma FFA rise observed in the $4 \mathrm{~h}$ following the $i . v$. injection of HGH $(10 \mathrm{mg})$ was not statistically different in obese females, normal males and normal females. - These results suggest that human obese adipose tissue has no impaired sensitivity toward the lipolytic action of NE and HGH. - During fasting, obese, when compared with normal subjects, showed a smaller increase in plasma FFA level together with a smaller decrease in glucose flux. The possible relationship between these 2 anomalies is discussed, considering that glucose deficiency has a major role in regulating FFA mobilization during fasting.
\end{abstract}

Influence de la noradrénaline, de l'hormone de croissance et du jê̂ne sur la mobilisation des FFA et sur le métabolisme glucidique chez des sujets obèses et normaux

Résumé. L'action de la noradrénaline, de l'hormone de croissance et du jeûne sur la mobilisation des FFA et sur le métabolisme glucidique a été comparée chez 47 femmes obèses et 72 sujets témoins ( 35 femmes et 37 hommes). - Perfusée pendant $2 \mathrm{~h}$ à une dose proportionnelle au poids $(\overline{0.1} \gamma / \mathrm{kg} / \mathrm{min})$, la noradrénaline provoque un accroissement des FFA plasmatiques et de la glycémie qui est beaucoup plus important chez les obèses que chez les normaux. Avec une dose fixe de $10 \% /$ min pendant $2 \mathrm{~h}$, l'élévation des FFA est encore significativement plus élevée chez les sujets obèses alors que l'effet hyperglycémiant est de même amplitude dans les 2 groupes. Parmi les sujets témoins, il n'y a pas de différence significative entre les réponses des 2 sexes. L'élévation des FFA mesurée pendant les $4 \mathrm{~h}$ suivant l'injection i.v. d'hormone de croissance humaine $(10 \mathrm{mg})$ est comparable chez les femmes obèses et les sujets témoins des 2 sexes. - Ces données suggèrent que le tissu adipeux des obèses présente une sensibilité normale à l'action de la noradrénaline et de l'hormone de croissanco. - Lorsqu'ils sont soumis au jeûne, les patients obèses présentent un accroissement moindre des FFA et une réduction moins marquée du flux glucosé que les sujets normaux. Les relations possibles entre ces deux anomalies sont discutées en tenant compte du rôle majeur que joue la carence en glucose dans la mobilisation lipidique au cours du jeûne.

Einfluß von Noradrenalin, Wachstumshormon und Fasten auf die FFS-Freisetzung und den Glucosestoffwechsel bei Übergewichtigen und Normalpersonen

Zusammenfassung. Die Wirkung von Noradrenalin, Wachstumshormon und Fasten auf die Mobilisierung der freien Fettsäuren und den Glucosestoffwechsel wurde bei 47 übergewichtigen Frauen und 72 Kontrollpersonen (35 Frauen und 37 Männern) verglichen. - Nach einer zweistündigen Infusion mit $0,1 \mu \mathrm{g} / \mathrm{kg} / \mathrm{min}$ führte das Noradrenalin zu einem Anstieg der Plasma-FFS und des Blutzuckerspiegels, der bei den U̇bergewichtigen wesentlich stärker ausgeprägt war als bei den Normalpersonen. Mit einer konstanten Dosis von $10 \mu \mathrm{g} / \mathrm{min}$ fiel die Steigerung der FFS bei den Adipösen immer noch signifikant höher aus, während der blutzuckersteigernde Effekt in beiden Kollektiven die gleiche Größenordnung erreichte. Die Kontrollpersonen zeigten keinen signifikanten Unterschied im Verhalten der beiden Geschlechter. - Die Erhöhung der FFS nach i.v. Verabreichung von menschlichem Wachstumshormon $(10 \mathrm{mg})$ wurde über 4 Std. verfolgt, wobei sich keine Unterschiede zwischen den übergewichtigen Frauen und den Normalpersonen beider Geschlechter ergaben. - Diese Ergebnisse lassen vermuten, daß das Fettgewebe bei Adipösen eine normale Empfindlichkeit gegenüber der Wirkung von Noradrenalin und Somatotropin aufweist. - Fasten führte bei den übergewichtigen Patienten zu einem geringeren Anstieg der FFS und zu einer weniger ausgeprägten Reduktion des Glucoseabstroms als bei den Kontrollpersonen. Die möglichen Beziehungen zwischen den beiden Anomalien werden unter Berücksichtigung der Rolle diskutiert, die die der Glucosemangel bei der Fettmobilisierung während. des Fastens spielt.

Key-words : Norepinephrine, fasting, FFA mobilization, glucose metabolism, obesity.
The role of an impaired lipid mobilization in the development and persistence of human obesity has been suspected for a long time on the basis of clinical observations: 1. some overweight subjects have the utmost difficulty in losing weight under caloric restriction; 2. obese subjects are frequently resistant to fasting ketosis. This concept has been confirmed in experiments in which obese subjects showed a subnormal rise in free fatty acids (FFA) when submitted to fast $[5,19,17,1]$.

The physiologic mechanism of the lipid mobilization produced by fasting could be altered in obesity 
either at the adipose tissue level (for example through anomalies of the lipase) or at the level of hormonal and nervous control.

The first possibility has been tested in the present work by studying the FFA response of overweight and normal subjects to the action of exogenous lipolytic hormones: norepinephrine (NE) and human growth hormone (HGH). No impairment of lipolysis could be demonstrated.

Some limited aspects of the second possibility have been investigated by correlating the altered lipid mobilization observed in obese subjects during fasting with the concomitant anomalies in changes in carbohydrate metabolism. There is some evidence indeed, that hormonal and nervous control in fasting could be mediated by diminished glucose availability to cells [3].

\section{Subjects and Methods}

The explored subjects included:

1. 72 non-obese control subjects (35 females and 37 males), aged 15 to 62 years (mean 35 years), ambulatory volunteers or hospitalized and convalescent from benign diseases with no relationship with lipid or carbohydrate metabolism. Weights ranged from $-27 \%$ to $+19 \%$ (mean value $-2 \%$ ) of "ideal" weight estimated from standard height-weight tables.

2. 47 obese subjects, all females, ambulatory or hospitalized for weight reduction. Most of them had slightly abnormal oral glucose tolerance tests (O.G.T. T), but none showed blood sugar levels higher than $120 \mathrm{mg} / 100 \mathrm{ml}$ at the $2^{\text {nd }} \mathrm{hr}$ of the O.G.T.T. Their ages ranged from 15 to 55 years with a mean of 33 years. Body weights were from $23 \%$ to $148 \%$ above "ideal" weight with a mean of $64 \%$.

Three types of studies were performed:

1. Norepinephrine $(N E)$ studies. After a control period of $15 \mathrm{~min}$, NE diluted in saline was infused at a constant rate of either $0.1 \gamma / \mathrm{kg} / \mathrm{min}$ or $10 \gamma / \mathrm{min}$ for $2 \mathrm{~h}$. Blood samples were drawn at intervals for estimation of glucose and FFA. Only small variations in blood pressure and pulse rate were observed during the experiments.

2. Human growth hormone $(H G H)$ studies. $10 \mathrm{mg}$ of HGH (prepared according to the method of RABEN [21]) was injected by the rapid $i . v$. route and the modifications of glucose and FFA were followed for $4 \mathrm{~h}$.

3. Fasting studies. Plasma FFA and blood glucose levels, and $K$ value (obtained from an $i . v$. glucose tolerance test using $0.33 \mathrm{~g} / \mathrm{kg}$ ) were determined first after a standard $15 \mathrm{~h}$ fast, and secondly after the prolongation of the fast for an additional $24 \mathrm{~h}$ (i.e. $39 \mathrm{~h}$ fast).

The product of the disappearance rate constant ( $K$ value expressed in $\mathrm{min}^{-1}$ ) and the basal glucose concentration $(\mathrm{mg} / 100 \mathrm{ml})$ yields the glucose flux $(\mathrm{mg} /$ $\min / 100 \mathrm{ml}$ of extracellular fluid). This type of calculation overestimates the glucose flux since the reactive
$K$ value is about $12 \%$ higher than the basal $K$ value measured using radioglucose [7], the difference being caused by the insulin release induced by hyperglycaemia. However, in the present study, it can be used as a comparative index, determinations being made in the same subjects and under the same loading conditions before and after the fast.

The experiments were performed at 9 a.m. after a $15 \mathrm{~h}$ fast, unless otherwise specified. The patients were resting for at least $30 \mathrm{~min}$ before the basal levels of glucose and FFA were measured, and remained in recumbent position throughout the tests.

Blood specimens were drawn from an indwelling needle located in a superficial antecubital vein.

FFA concentration was determined by DoLE's procedure [6] on plasma obtained from heparinized blood samples centrifuged under refrigeration and kept at $-20^{\circ} \mathrm{C}$ until the day of the analysis. Total blood glucose was estimated by the method of HoFrMAN [13] adapted to the TECHNICON Autoanalyzer.

\section{Results}

\section{Norepinephrine ( $N E$ ) experiments}

Data corresponding to these experiments are shown in Fig. 1 and 2. As well for obese as for lean patients, NE increased FFA levels; a peak was reached either $30 \mathrm{~min}$ or $60 \mathrm{~min}$ after starting infusion. Thereafter FFA decreased slowly despite the maintenance of the infusion. A similar pattern was noticed for glucose modifications.

Differences between normal and obese subjects were submitted to statistical analysis; with this object, increments above basal values, observed at 30 and 60 min were pooled.

Results were different with weight-related doses and with fixed doses.

a) $N E 0.1 \mathrm{\gamma} / \mathrm{kg} / \mathrm{min}$ (Fig. 1). In the control group (4 males and 5 females), the mean FFA basal level was $0.660 \mathrm{mEq} / 1 ; 30 \mathrm{~min}$ and $60 \mathrm{~min}$ after starting infusion, the increases were respectively $+0.390 \mathrm{mEq} / \mathrm{l}$ and + $0.292 \mathrm{mEq} / 1$.

In the obese subjects (all females), FFA mean basal value was $0.926 \mathrm{mEq} / 1$. The $\mathrm{NE}$-induced rise was more pronounced and more delayed than in normal subjects $\left(+0.901 \mathrm{mEq} / 1\right.$ at the $30^{\text {th }}$ min and 0.970 $\mathrm{mEq} / \mathrm{l}$ at the $60^{\text {th }} \mathrm{min}$ ). Statistical analysis of the difference between the 2 groups, calculated as previously mentioned, showed a high degree of significance $(t=7.2 p<0.001)$.

The mean basal blood glucose concentration was somewhat higher in obese $(85 \mathrm{mg} / 100 \mathrm{ml}$ ) than in normal subjects $(77 \mathrm{mg} / 100 \mathrm{ml})$. The NE-induced hyperglycaemia was more important in the former $(+$ $21 \mathrm{mg} / 100 \mathrm{ml}$ at the $30^{\text {th }} \mathrm{min}$ and $+25 \mathrm{mg} / 100 \mathrm{ml}$ at the $\left.60^{\text {th }} \mathrm{min}\right)$ than in the latter $(+15 \mathrm{mg} / 100 \mathrm{ml}$ at the $30^{\text {th }} \mathrm{min}$ and $+14 \mathrm{mg} / 100 \mathrm{ml}$ at the $60^{\text {th }} \mathrm{min}$ ). 
This difference was highly significant $(t=3.1,0.001<$ $\mathrm{p}<0.01$ ).

b) $N E 10 \gamma / \min$ (Fig. 2). Basal values for FFA averaged $0.623 \mathrm{mEq} / \mathrm{l}$ in normal males, $0.665 \mathrm{mEq} / 1$ in normal females and $0.720 \mathrm{mEq} / 1$ in obese females. In

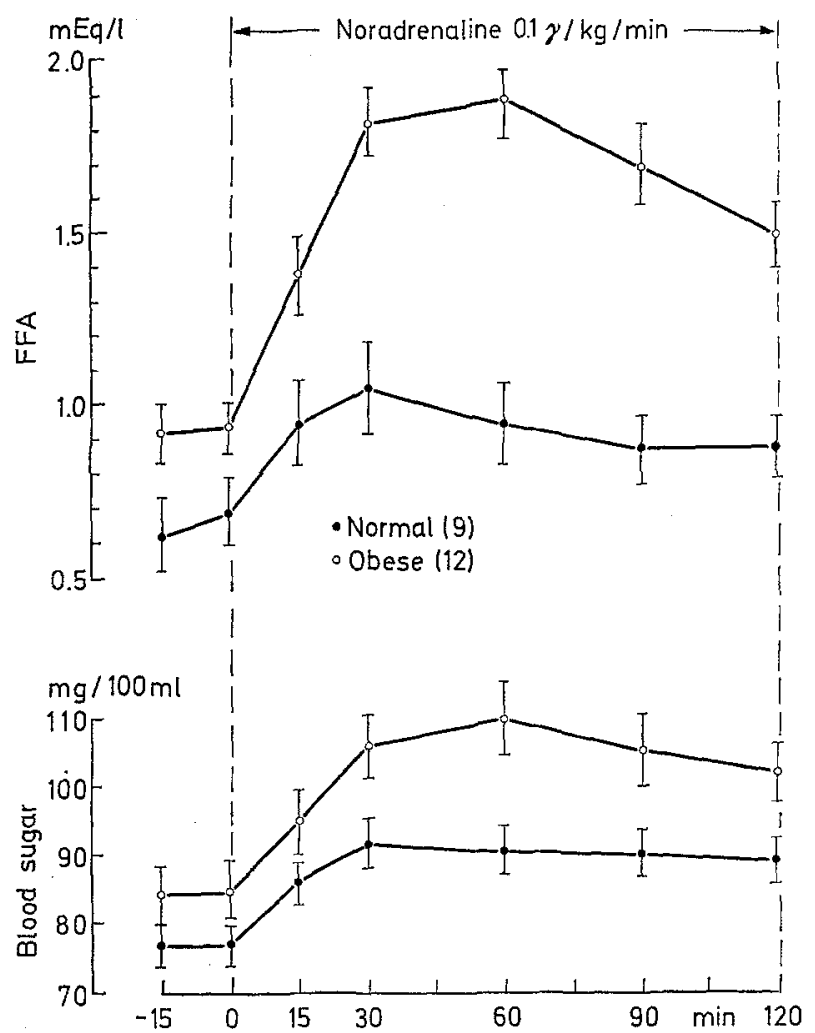

Fig. 1. Action of noradrenaline infused at a weight-related dose, on plasma FFA and blood glucose concentrations in normal (4 males and 5 females) and obese (all females) subjects; mean results \pm S.E.M.

the control group, the FFA increase during the NE infusion was somewhat higher in females $(+0.809$ $\mathrm{mEq} / \mathrm{l}$ at the $30^{\mathrm{th}} \mathrm{min}$ and $+0.683 \mathrm{mEq} / \mathrm{l}$ at the $60^{\text {th }} \mathrm{min}$ ) than in males $\left(+0.654 \mathrm{mEq} / \mathrm{l}\right.$ at the $30^{\text {th }}$ min and $+0.597 \mathrm{mEq} / \mathrm{l}$ at the $60^{\text {th }} \mathrm{min}$ ), but the difference had no statistical significance $(t=1.7, p>$ $0.05)$. In the obese group, however the increase in FFA $\left(+1.083 \mathrm{mEq} / \mathrm{l}\right.$ at the $30^{\mathrm{th}} \mathrm{min}$ and $+1.107 \mathrm{mEq} / \mathrm{l}$ at the $60^{\text {th }} \mathrm{min}$ ) was significantly greater than the one observed with normal females $(t=4.1, p<0.001)$ and normal males $(t=5.3, p<0.001)$.

No appreciable difference was found among the 3 groups of subjects, either for basal glucose concentration, or for the NE-induced hyperglycaemia.

$H G H$ experiments (Fig. 3 )

The mean FFA level at time zero was higher in obese females $(0.783 \mathrm{mEq} / \mathrm{l})$ than in normal females $(0.561 \mathrm{mEq} / \mathrm{l})$ and normal males $(0.490 \mathrm{mEq} / \mathrm{l})$. During the $1^{\mathrm{st}} \mathrm{h}$, no significant change in FFA occured; thereafter a significant increase was observed in all subjects. The mean maximal increase averaged $+0.620 \mathrm{mEq} / 1$ at the $4^{\text {th }} \mathrm{h}$ in obese females, $+0.518 \mathrm{mEq} / \mathrm{l}$ at the $3^{\text {rd }} \mathrm{h}$ in normal females and $+0.481 \mathrm{mEq} / \mathrm{l}$ at the $4^{\text {th }}$ $h$ in normal males. The differences between males and females, and between normal and obese females, when calculated on the pooled FFA increases observed from the $2^{\text {nd }}$ to the $4^{\text {th }} \mathrm{h}$, had no statistical meaning.

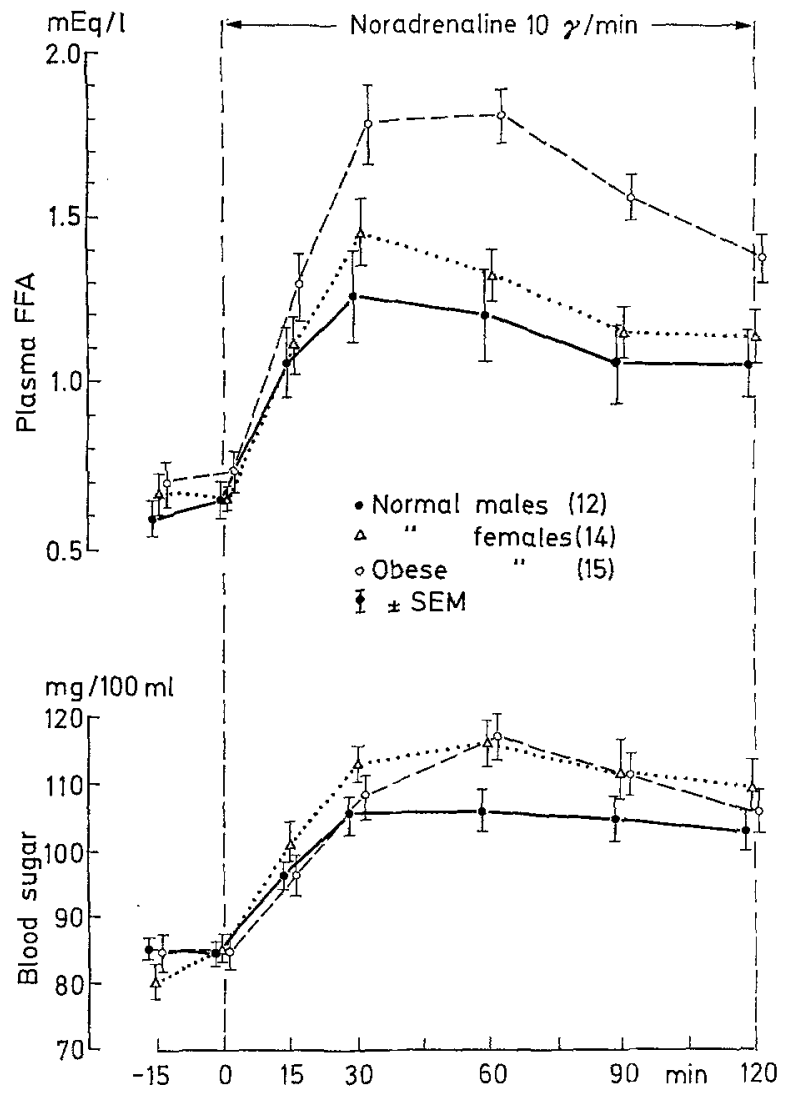

Fig. 2. Action of noradrenaline infused at a fixed dose on plasma FEA and blood glucose concentrations in normal males, normal females and obese females; mean results \pm S.E.M.

In each group, the blood sugar dropped slightly but not significantly at the $1^{\text {st }} \mathrm{h}$ and subsequently returned to basal values.

\section{Fasting experiments}

Changes in FFA concentration and carbohydrate metabolism induced by progressive fasting in normal and obese subjects are shown in the Table together with the corresponding statistical data.

When compared with normal subjects, obese showed at the $15^{\text {th }} \mathrm{h}$ of the fast similar mean glucose levels, lower mean $K$ values and glucose fluxes, and higher mean FFA concentrations.

From the $15^{\text {th }}$ to the $39^{\text {th }} \mathrm{h}$ of the fast, mean blood sugar concentration, $K$ value and glucose flux decreased in both groups, while mean FFA concentrations increased; the modifications were significantly smaller in obese subjects except for the glycaemia.

At the $39^{\text {th }} \mathrm{h}$ of the fast, both groups were in comparable metabolic situations, as far as the studied parameters were concerned. 
Table. Changes in carbohydrate and FF A metabolism induced by fasting in obese and control subjects (mean values \pm S.E.M.)

\begin{tabular}{|c|c|c|c|c|c|c|c|c|c|}
\hline & \multicolumn{3}{|c|}{$15^{\text {th }}$ h F Fasting } & \multicolumn{3}{|c|}{$39^{\text {th }}$-h Fasting } & \multicolumn{3}{|l|}{$\Delta\left(39^{\text {th }}-\mathrm{h} 15^{\mathrm{th}-\mathrm{h}}\right)$} \\
\hline & Control $^{1}$ & Obese ${ }^{2}$ & $P$ Value & Control ${ }^{1}$ & Obese $^{2}$ & $P$ Value & Control $^{1}$ & Obese $^{2}$ & $P$ Value \\
\hline $\begin{array}{l}\text { Blood Sugar } \\
(\mathrm{mg} / 100 \mathrm{ml})\end{array}$ & $82.0 \pm 2.1$ & $83.1 \pm 2.9$ & $P>0.05$ & $74.9 \pm 2.2$ & $79.8 \pm 2.4$ & $P>0.05$ & $-7.1 \pm 1.2$ & $-3.3 \pm 3.0$ & $P>0.05$ \\
\hline $\mathrm{K} 10^{2}\left(\min ^{-1}\right)$ & $1.48 \pm 0.1$ & $0.89 \pm 0.07$ & $0.001<P<0.01$ & $0.97 \pm 0.06$ & $0.84 \pm 0.09$ & $P>0.05$ & $-0.52 \pm 0.14$ & $-0.15 \pm 0.05$ & $P=0.05$ \\
\hline $\begin{array}{l}\text { Glucose flux } \\
(\mathrm{mg} / 100 \mathrm{ml} / \mathrm{min})\end{array}$ & $1.22 \pm 0.15$ & $0.82 \pm 0.06$ & $0.02<P<0.05$ & $0.71 \pm 0.05$ & $0.67 \pm 0.07$ & $P>0.05$ & $-0.51 \pm 0.12$ & $-0.15 \pm 0.05$ & $0.02<P<0.05$ \\
\hline FFA $(\mathrm{mEq} / 1)$ & $0.57 \pm 0.038$ & $0.782 \pm 0.090$ & $P=0.02$ & $1.1 \pm 0.066$ & $0.979 \pm 0.075$ & $P>0.05$ & $+0.540 \pm 0.054$ & $+0.197 \pm 0.074$ & $P<0.001$ \\
\hline
\end{tabular}

1 Mean results for 18 control subjects (12 males and 6 females).

2 Mean results for 10 obese subjects (1 male and 9 females).
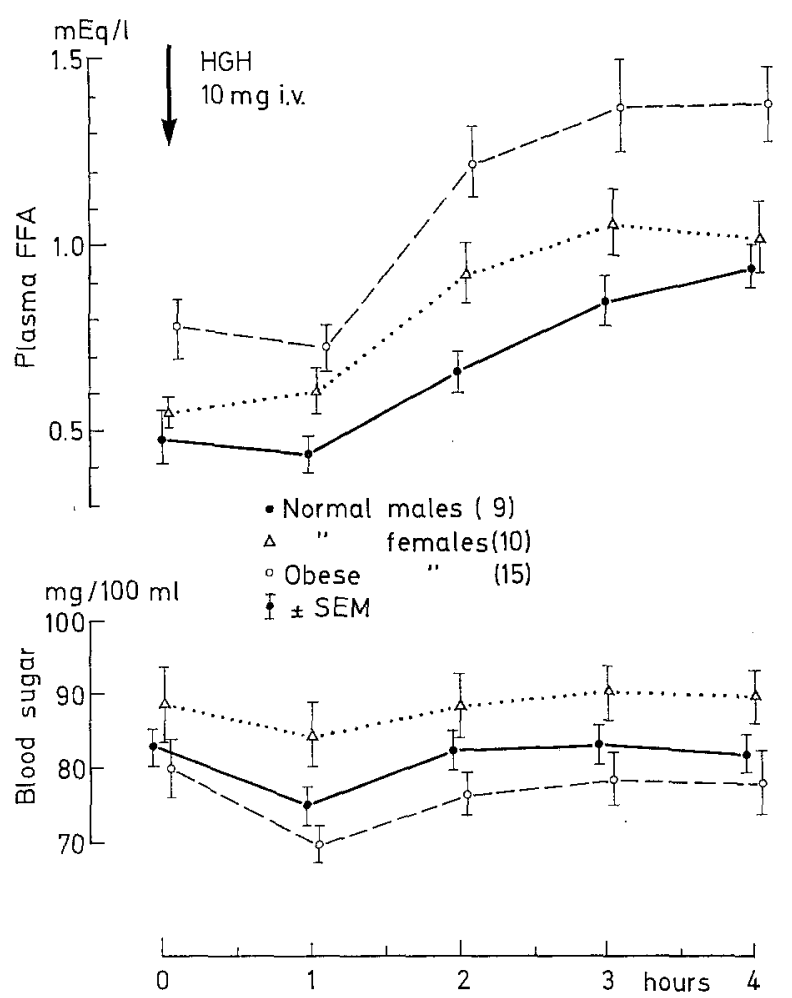

Fig. 3. Action of human growth hormone (10 $\mathrm{mg} i . v$.) on plasma FFA and blood glucose concentrations in normal males, normal females and obese females; mean results \pm S.E.M.

\section{Discussion}

Norepinephrine ( $N E)$ Infusion experiments

When using a weight-related dose $(0.1 \gamma / \mathrm{kg} / \mathrm{min})$, the FFA increase observed in obese patients was approximately double that obtained in normal subjects. This is probably related to the higher absolute amounts of NE injected in the overweight subjects, as a greater increase in blood sugar was simultaneously observed.

When a fixed dose of NE was used (10 $\gamma / \mathrm{min})$, a supranormal FFA response was still manifest in obese subjects, while hyperglycaemia was approximately of the same magnitude in obese and in normal controls of both sexes. That the adipose tissue of the obese had a reduced sensitivity to NE is therefore most unlikely.
The greater increase in FFA observed in overweight patients might have resulted from their greater adipose tissue mass.

Our results are somewhat discordant with other reports. ORTH et al. [20], infusing normal and obese women with amounts of epinephrine related to body weight, observed no difference in the FFA response. GoLdBerg and Gordon [10] have studied FFA modifications $30 \mathrm{~min}$ after subcutaneous injection of a standard dose of epinephrine $(0.5 \mathrm{mg})$; lipid mobilization was found to be normal in subjects in a dynamic state of obesity and subnormal in patients with long standing, therapeutically-resistant obesity. We are not able to make such a distinction among our results. In a more recent study, GLENNoN, BRECH and GoRdon [9] observed that the mean rise in FFA after subcutaneous epinephrine was smaller in obese than in normal controls, but that the number of low responses was the same in both groups.

Our results are corroborated by data obtained in vitro: GALTON and BRAY [8] observed that human adipose cells, isolated from normal or obese patients, increased in the same proportion their FFA release in the presence of epinephrine. Mostrater et al. [18] observed even a greater lipolytic action of epinephrine on obese human adipose tissue than on normal tissue.

The mean lipolytic action of NE was found to be more important in lean females than in lean males. Although this difference was not significant, the role of sex in lipid mobilization can reasonably be considered in the view of a report showing a higher degree of fasting ketosis in female than in males subjects [2].

\section{HGH Experiments}

The rise in FFA was of the same magnitude in obese females and lean subjects of both sexes. This was also pointed out by MAUTaren et al. [16], using doses related to body weight. Therefore, as for $\mathrm{NE}$, the lipolytic effect of HGH does not seem to be diminished in human obesity.

\section{Fasting experiments}

Fasting is characterized by a reduction in glucose availability to cells. This provokes a decrease in FFA reësterification in adipose tissue [24], an increase in the secretion of lipolytic hormones (HGH [22] and 
glucagon [23] and probably in sympathetic nervous activity [12]. These adaptative mechanisms to glucose lack increase FFA concentration by stimulating release of the latter from adipose tissue.

In agreement with data from the literature $[5,19$, $17,1]$ our results show a subnormal rise in FFA level during fasting in obesity.

The role of a reduced sensitivity of obese adipose tissue to lipolytic substances (HGH or catecholamines) is improbable on the basis of our experiments in vivo with exogenous hormones and on the basis of the previously mentioned results obtained in vitro.

The modifications of carbohydrate metabolism produced by fasting might provide a partial explanation for the smaller FFA response observed in obese subjects; during fasting indeed, these subjects show a smaller impairment of glucose flux into cells when compared with normal subjects. This might account for the smaller increase in serum FFA, since glucose deprivation plays a key role in the control of lipid mobilization during fasting. In agreement with this concept are the observations of an insufficient $\mathrm{HGH}$ response to fasting in obesity [1,22].

It is not known why obese subjects show smaller decreases in blood sugar and $K$ value than normal subjects when submitted to a fast of the same duration. KECKWICK et al. [14] made similar observations regarding glucose level in subjects submitted to a low carbohydrate diet; they suggested that overweight patients are able to convert more easily lipids to glucose under such circumstances.

Our hypothesis that the smaller lipid mobilization observed in the starved obese patients might be related to the greater stability of the rate of their glucose utilization only affords a partial explanation. Indeed, a deficiency of FFA mobilization in obesity has been described in situations other than fasting: psychological stress [15], cold exposure [11], muscular exercise [19]. This suggests the existence in obesity of a fundamental defect in the secretion of lipolytic hormones and / or in the responsiveness of the adrenergic nervous system. Such an anomaly has been demonstrated for the secretion of growth hormone in response to various stimuli (insulinic hypoglycaemia [1], muscular exercise [22], arginine infusion [4]).

Acknowledgments. We wish to thank Dr J. CorvutaIN for the generous supply of human growth hormone.

Our gratitude goes to Prof. P.A. Bastenie, Prof. V. ConARD and Dr J.R.M. Franckson for useful advice and constructive criticisms.

\section{References}

1. Beck, P., J.H.T. Koumans, C.A. Winterling, M.F. STEIN, W.H. DAUGHADAY, and D.M. KIPNIS: Studies of insulin and growth hormone secretion in human obesity. J. Lab. clin. Med. 64, 654-667 (1964).
2. Bloom, W.L., G. Azar, J. Clakk, and J.H. Mackay: Comparison of metabolic changes in fasting obese and lean patients. Ann. N.Y. Acad. Sci. 131, 623631 (1965).

3. Carlson, L.A., J. Boberg, and B. Högstedt in A.E. Rerold and G.F. CAHILr Jr.: Handbook of Physiology - Adipose tissue. Washington, D.C. American Physiological Society, p. 625, 1965 .

4. Copinschi, G., L.C. Wegrenka, S. Hane, and P.H. Forsham: Effect of arginine on serum levels of insulin and growth hormone in obese subjects. Metabolism (in press).

5. Corvilain, J., H. Loeb, A. Champenots, and M. ABRAMOW: Effect of fasting on levels of plasma-
nonesterified fatty acids in normal children, normal adults and obese adults. Lancet $1961 \mathrm{I}, \mathbf{5 3 4 - 5 3 5}$.

6. Dotw, V.P.: A relation between the non-esterified fatty acids in plasma and the metabolism of glucose. J. clin. Invest. 35, $150-154$ (1956).

7. Franckson, J.R.M., H.A. Ooms, R. Bellens, V. Conard, and P.A. Basterie: Physiologic significance of the intravenous glucose tolerance test. Metabolism 11, 482-500 (1962).

8. Galton, D.J., and G.A. Bray: Effects of epinephrine on isolated adipose cells from normal and overweight patients. J. clin. Invest. 45, 1010 (1966) (abstract).

9. Glennon, J.A., W.J. BrECH, and E.S. Gordon: Evaluation of an epinephrine test in obesity. Metabolism 14, 1240-1242 (1965).

10. Goldpera, M., and E.S. Gordon: Energy metabolism in human obesity. Plasma FFA, glucose and glycerol response to epinephrine. J. amer. med. Ass. 189, 616-623 (1964).

11. Gordon, E.S.: The lipolytic effect of exposure to cold in human subjects. Diabetologia 1, 75 (1965) (abstract).

12. HAVEL, R.J., in A.E. RENoLD, and G.F. CAHILI JR.: Handbook of Physiology - Adipose Tissue. Washington, D.C., American Physiological Society, p. 575,1965 .

13. HofminaN, W.S.: A rapid photoelectric method for the determination of glucose in blood and urine. $J$. biol. Chem. 120, 51-55 (1937).

14. KFikwiCK, A., G.L.S. PaWAN, and T.M. Chalmers: Resistance to ketosis in obese subjects. Lancet 1959 II, $1157-1159$.

15. KleiN, R.F., W.G. Troyer, K.W. Back, T.C. Hood and M.D. BogdonOFF: Experimental stress and fat mobilization in lean and obese subjects. Metabolism 14, 17-25 (1965).

16. Madtalen, C., and R.W. SintTh, JR.: Lipolytic effects of human growth hormone in resistant obesity. $J$. clin. Endocr. 25, 495-498 (1965).

17. Morse, W.I., and R. MAHABIR: Changes in glucoso tolerance and plasma free fatty acids after fasting in obesity. Diabetes 13, 286-290 (1964).

18. Mosinger, R., E. KuHN, and V. KUJalova: Action of adipokinetic hormones on human adipose tissue in vitro. J. Lab. clin. Med. 66, 380-389 (1965).

19. OpIE, L.H., and P.G. WAIIISCH: Plasma free fatty acid concentrations in obesity. New Engl. J. Med. 268, 757-760 (1963).

20. Orth, R.D., and R.H. Williams: Response of plasma NEFA levels to epinephrine infusions in normal and obese women. Proc. Soc. exp. Biol. (N.Y.) 104, 119-120 (1960).

21. RABEN, M.S.: Preparation of growth hormone from pituitary of Man and Monkey. Science 125, 883$884(1957)$. 
22. Roth, J., S.M. GLICK, R.S. YALOW, and S.A. BeRsoN-Secretion of human growth hormone: Physiologic and experimental modification. Metabolism 12, $577-579$ (1963).

23. Unger, R.H., A.M. Eisentraut, and L.L. Madison: The effects of total starvation upon the levels of circulating glucagon and insulin in man. J. clin. Invest. 42, $1031-1039$ (1963).
24. VAUGHAN, M.: The metabolism of adipose tissue in vitro. J. Lipid Res. 2, 293-316 (1961).

E. Batasse

Laboratoire de Médecine Expérimentale

Université libre de Bruxelles

115, Boulevard de Waterloo

Bruxelles 1, Belgium 